\title{
Antifungal Effect of Three Local Malaysian Honeys on Selected Pathogenic Fungi of Otomycosis: An in vitro Evaluation
}

\author{
Zubaidah Hamid', Irfan Mohamad ${ }^{*}$, Azian Harun², Rosdan Salim', Siti Amrah Sulaiman 3,4 \\ 'Department of Otorhinolaryngology-Head and Neck Surgery, School of Medical Sciences, Universiti Sains Malaysia, 16150 Kubang Kerian, Kelantan, MALAYSIA. \\ 2Department of Medical Microbiology and Parasitology, School of Medical Sciences, Universiti Sains Malaysia, 16150 Kubang Kerian, Kelantan, MALAYSIA. \\ ${ }^{3}$ Department of Pharmacology, School of Medical Sciences, Universiti Sains Malaysia, 16150 Kubang Kerian, Kelantan, MALAYSIA. \\ ${ }^{4}$ Hospital Universiti Sains Malaysia, Health Campus, USM, 16150 Kubang Kerian, Kelantan, MALAYSIA.
}

\begin{abstract}
Background: Otomycosis has been reported to be prevalent in tropical and sub-tropical regions. The causative pathogens causing otomycosis include Aspergillus niger and Candida albicans, for which the antifungal treatment regime has not been clearly standardized. Honey is a natural product which has been widely studied for various properties, including antimicrobial properties. This study was aimed at determining the antifungal activities of three types of Malaysian honey; Tualang, Acacia and Kelulut honey, against fungal pathogens of otomycosis. Methods: The honey samples were examined for antifungal activity against Aspergillus niger and Candida albicans. Honey was incorporated into Sabouraud dextrose agar at concentrations of $5 \%$ (v/v), 10\% (v/v), 20\% (v/v) and 25\% (v/v). Conidial suspension was inoculated and spread onto honey-SDA agar plates. After incubation colony counts were determined. Results: The honey samples demonstrated varying levels of inhibitory activity at various concentrations against the fungi tested with colony count reducing with increasing honey concentration. All three honeys showed total growth inhibition at $25 \%(\mathrm{v} / \mathrm{v})$
\end{abstract}

concentration. Comparing the three types of honey, Kelulut honey was shown to be the most active against the tested fungi. Conclusion: The three honeys used in the study showed promising antifungal activity. Malaysian honeys have shown potential as antifungal substances for possible development of antifungal drugs for the treatment of fungal infections such as otomycosis.

Key words: Malaysia, Honey, Otomycosis, Aspergillus niger, Candida albicans. Correspondence

Dr. Irfan Mohamad, Department of Otorhinolaryngology-Head and Neck Surgery, School of Medical Sciences, Universiti Sains Malaysia Health Campus, 16150 Kota Bharu, Kelantan, MALAYSIA.

Phone: +06-9-7676416

Email: irfankb@usm.my

DOI: 10.5530/jyp.2018.10.91

\section{INTRODUCTION}

Otomycosis is defined as superficial fungal infection of the outer ear canal. ${ }^{1}$ Otomycosis has world-wide distribution, with higher prevalence in tropical and sub-tropical regions due to the hot, humid and dusty climate. ${ }^{2}$ Nevertheless studies pertaining prevalence of otomycosis remains scarce, despite its high occurrences particularly in tropical countries. Many species of fungi have been identified as causative agents of otomycosis. However, Aspergillus niger is the most commonly described agent in the literature, followed by Candida albicans. Antifungal medications vary widely, and no consensus has been derived as to which medications are most effective in otomycosis. ${ }^{3}$ Furthermore, in recent years, there are increasing antifungal drugs resistance. This drives the need to pursue for natural solution which is more effective and safe. Honey, a natural solution has been used as medicinal products since ancient times. Its antibacterial properties have been extensively documented. ${ }^{4}$ Nevertheless, studies on antifungal effects of local honeys are still limited.

In Malaysia, they are various types of local honeys available for consumptions. However, no extensive studies on their antifungal properties have been conducted. ${ }^{4-6}$ The three types of honey used in this study were selected based on their unique properties. Tualang honey is a multifloral honey, meanwhile Acacia honey is extraflorial honey, and Kelulut honey is derived from stingless bee. To the best of our knowledge, based on research and English literature review, this is the first study on the antifungal properties of different types of Malaysian local honey against two most common pathogenic fungi of otomycosis (A. niger and C. albicans).

\section{MATERIALS AND METHODS}

\section{Fungal isolates}

A. niger and C. albicans were obtained from the Mycology Laboratory, Department of Medical Microbiology and Parasitology, School of Medical Sciences, Universiti Sains Malaysia. These fungi have been isolated from patients with otomycosis. A. niger was identified based on microscopic features. ${ }^{7}$ Identification of C. albicans was based on the morphology on slide culture and biochemical characteristics by API 20C AUX (bioMerieux, France).

\section{Honey samples}

Tualang Honey was obtained from Federal Agriculture Marketing Authority (FAMA), Kedah, Malaysia. Meanwhile, Acacia honey and Kelulut honey were supplied by the USM-BJIM Project (Medicinal Trigonal Bee Rearing project). The honeys used in this study have been subjected to sterilization by $25 \mathrm{kGy}$ gamma-irradiation.

\section{Preparation of conidial suspension}

A. niger was subcultured on Sabouraud dextrose agar (SDA) (Oxoid, $\mathrm{UK}$ ) and incubated at $30^{\circ} \mathrm{C}$. Upon $48 \mathrm{~h}$ of incubation, the well grown sporulating colony was flooded with $5 \mathrm{ml}$ of sterile water. The surface of the colony, which contained spores, was lightly scraped using sterile cotton swab. The mixture was filtered through sterile gauze to remove mycelia and debris. The filtrate containing conidia was then transferred to a sterile tube. Sterile water was added to the suspension until it reached turbidity of 0.5 MacFarland, which corresponded to $1-5 \times 10^{6} \mathrm{cfu} / \mathrm{ml}$. 
C. albicans was sub cultured on SDA plate. Following 24-h incubation at $30^{\circ} \mathrm{C}$, the colonies were scraped using sterile cotton swab and dipped into a sterile tube containing $3 \mathrm{ml}$ of distilled water. The suspension turbidity was adjusted by adding sterile water to obtain turbidity of 0.5 MacFarland.T

Dilutions were made to produce conidial suspensions of $5 \times 10^{3}$ and $5 \times 10^{2}$ $\mathrm{cfu} / \mathrm{ml}$ concentration. For each dilution, $100 \mathrm{ml}$ of suspension was inoculated onto SDA for verification conidial concentration. The conidial suspension concentration of $5 \times 10^{3} \mathrm{cfu} / \mathrm{ml}$ was eventually used as standard inoculum concentration for this study.

\section{Preparation of honey-incorporated culture media}

Plain SDA agar plate was prepared in accordance to manufacturer's instruction. Honey was added to SDA medium after sterilization prior to pouring into Petri dishes. The amount of honey incorporated into the medium was titrated to make up the following concentration; $5 \%(\mathrm{v} / \mathrm{v})$, $10 \%(\mathrm{v} / \mathrm{v}), 15 \%(\mathrm{v} / \mathrm{v})$ and $25 \%(\mathrm{v} / \mathrm{v})$. Samples of prepared honey-SDA plates were incubated at $30^{\circ} \mathrm{C}$ for $24 \mathrm{~h}$ to check for contamination. All prepared plates were stored at $4^{\circ} \mathrm{C}$ prior to use.

\section{Plate count procedure}

Plate count procedure was performed based on previously reported study of similar purpose. ${ }^{8}$ All procedures were performed under aseptic condition. Freshly prepared conidial suspensions were vortexed to ensure homogenous suspension. One hundred microliter of conidial suspension was inoculated onto the prepared honey-SDA plates, in triplicates for each honey concentration. SDA plate without honey was used as control. The plates were incubated at $30^{\circ} \mathrm{C}$. Colony count was performed after 24 and $48 \mathrm{~h}$.

\section{Statistical analysis}

Paired $t$-test was used to analyse the data in this study.

\section{RESULTS}

The fungal growth inhibition by Tualang, Acacia and Kelulut honeys are shown in Table 1 and Table 2. All three types of honeys showed antifungal activities, in which significant reduction of colony counts was seen in comparison to control plate (SDA without honey).

Figure 1 shows the effects of the three honeys on A. niger at four different honey concentrations $(\mathrm{v} / \mathrm{v})$. Tualang honey showed gradual reduction in A. niger colony count with increasing honey concentration from $5 \%$ $(\mathrm{v} / \mathrm{v})$ to $15 \%(\mathrm{v} / \mathrm{v})$. No fungal colony seen at $25 \%(\mathrm{v} / \mathrm{v})$. As for Acacia honey, at $5 \%(\mathrm{v} / \mathrm{v})$, the colony counts of $A$. niger was rather similar to that of Tualang honey. At $10 \%(\mathrm{v} / \mathrm{v})$ Acacia honey plate showed lesser colony count. No A. niger colony was seen at $15 \%(\mathrm{v} / \mathrm{v})$ and $25 \%(\mathrm{v} / \mathrm{v})$ Acacia honey. Kelulut honey $5 \%$ (v/v) plate showed much lesser $A$. niger colony count compared to those of Tualang and Acacia honeys. No A. niger growth seen on $10 \%(\mathrm{v} / \mathrm{v}), 15 \%(\mathrm{v} / \mathrm{v})$ and $25 \%(\mathrm{v} / \mathrm{v})$ Kelulut honey plates. The effects of Tualang, Acacia and Kelulut honeys on C. albicans are shown in Figure 2. Tualang honey showed gradual reduction in C. albicans colony count. Total inhibition of C. albicans growth was seen at $25 \%$ (v/v) Tualang honey. Acacia honey, on the other hand, showed similar C. albicans colony count as Tualang honey at $5 \%(\mathrm{v} / \mathrm{v})$ but scanty growth at $10 \%(\mathrm{v} / \mathrm{v})$ and total growth inhibition at $15 \%(\mathrm{v} / \mathrm{v})$ and $25 \%(\mathrm{v} / \mathrm{v})$. Kelulut honey plates showed C. albicans colony count of less than $10 \mathrm{cfu}$ at $5 \%(\mathrm{v} / \mathrm{v})$, whereas at $10 \%(\mathrm{v} / \mathrm{v}), 15 \%(\mathrm{v} / \mathrm{v})$ and $25 \%(\mathrm{v} / \mathrm{v})$, total growth inhibition was noted. Therefore, comparing all types of honey, Kelulut honey seemed to have the strongest antifungal activity on both A. niger and C. albicans.

Table 1: Antifungal effects of Tualang, Kelulut and Acacia honeys on Aspergillus niger.

\begin{tabular}{cccccc}
\hline Honey & Group & $\begin{array}{c}\text { Colony count } \\
\text { Mean(SD) }\end{array}$ & $\begin{array}{c}\text { Mean difference } \\
(95 \% \mathrm{Cl})\end{array}$ & $\begin{array}{c}\text { t-statistics } \\
(\mathbf{d f})\end{array}$ & p-value \\
\hline Tualang & Tualang & $53.80(13.77)$ & $-70.10(-84.80,-55.40)$ & $-10.78(9)$ & $<0.001$ \\
& Control $^{\mathrm{b}}$ & $123.90(15.13)$ & & & \\
\multirow{2}{*}{ Kelulut } & Kelulut & $15.30(1.83)$ & $-108.60(-118.89,-98.31)$ & $-23.87(9)$ & $<0.001$ \\
& Control & $123.90(15.13)$ & & & \\
\multirow{2}{*}{ Acacia } & Acacia & $51.30(12.31)$ & $-72.60(-82.08,-63.12)$ & $-17.33(9)$ & $<0.001$ \\
& Control & $123.90(15.13)$ & & & \\
\hline
\end{tabular}

${ }^{a}$ Paired $t$-test was applied

${ }^{\mathrm{b} C}$ Control: SDA without honey

Table 2: Antifungal effects of Tualang, Kelulut and Acacia honeys on Candida albicans.

\begin{tabular}{cccccc}
\hline Honey & Group & $\begin{array}{c}\text { Colony count } \\
\text { Mean(SD) }\end{array}$ & $\begin{array}{c}\text { Mean difference } \\
(95 \% \mathrm{Cl})\end{array}$ & $\begin{array}{c}\text { t-statistics }^{\mathrm{a}} \\
(\mathbf{d f})\end{array}$ & p-value \\
\hline Tualang & Tualang & $74.70(16.52)$ & $-52.40(-62.19,-42.61)$ & $-12.11(9)$ & $<0.001$ \\
& Control $^{\mathrm{b}}$ & $127.10(16.52)$ & & & \\
\multirow{2}{*}{ Kelulut } & Kelulut & $2.20(1.40)$ & $-124.90(-137.16,-112.64)$ & $-23.04(9)$ & $<0.001$ \\
& Control & $127.10(16.52)$ & & & \\
\multirow{2}{*}{ Acacia } & Acacia & $34.40(4.60)$ & $-92.70(-103.39,-82.015)$ & $-19.63(9)$ & $<0.001$ \\
& Control & $127.10(16.52)$ & & & \\
\hline
\end{tabular}

a Paired $t$-test was applied

${ }^{\mathrm{b} C}$ Control: SDA without honey 


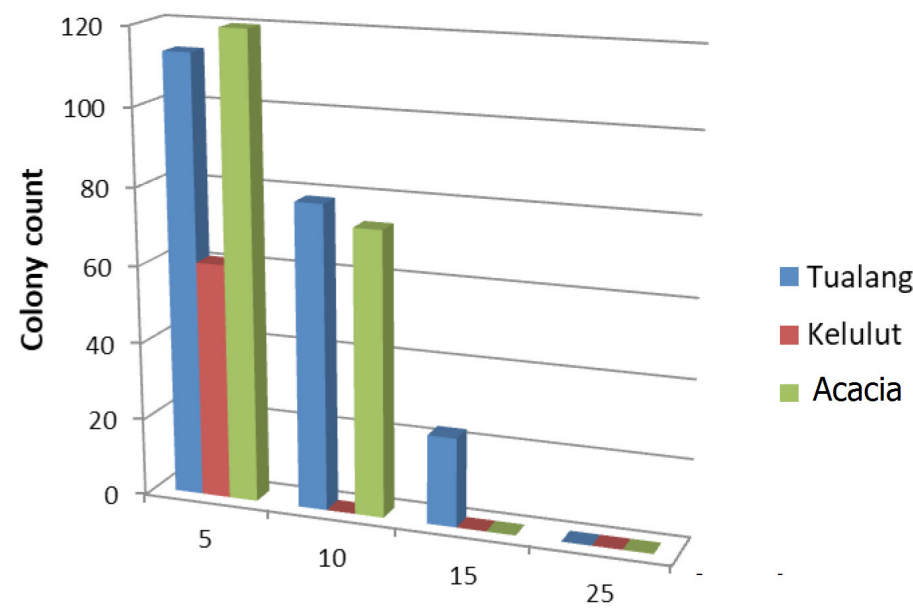

Percentage of honey $(\mathrm{v} / \mathrm{v})$

Figure 1: Effects of different concentrations of Tualang, Kelulut and Acacia honeys on Aspergillus niger.

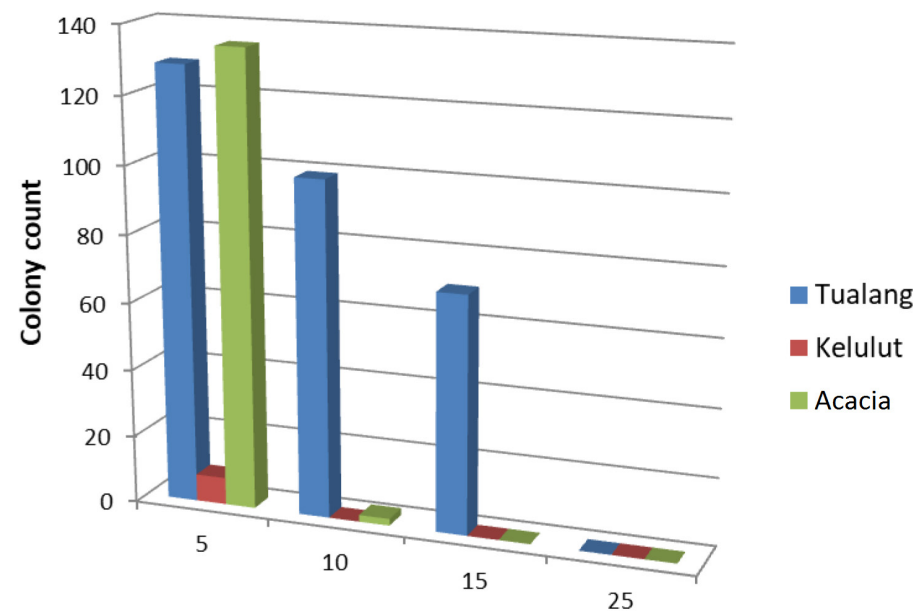

Percentage of honey $(\mathrm{v} / \mathrm{v})$

Figure 2: Effects of different concentrations of Tualang, Kelulut and Acacia honeys on Candida albicans.

\section{DISCUSSION}

In the present study all three types of honey, Tualang, Acacia and Kelulut, demonstrated significant antifungal properties against $A$. niger and C. albicans. This finding is in line with previously reported studies that depicted antifungal efficacy of various honey on fungi. Nevertheless, some studies did report selected fungal resistance to selected honey. ${ }^{9-10}$

The in vitro antifungal activity of honey was reported by Estevinho et al. (2011), who observed that honey inhibited the growth of C. albicans, C. krusei and Cryptococcus neoformans. ${ }^{11}$ Obaseik-Ebor and Afonya (1984) compared the antifungal activity of honey distillate with some antimycotic preparations against $C$. albicans and found that all the strains resistant to conventional antimycotic agents were inhibited by active fraction of honey. ${ }^{12}$ Boukraa and Bouchegrane (2007) reports in vitro antifungal efficacy of Algeria honey on A. niger and C. albicans. ${ }^{13}$ Meanwhile Moussa et al. also using Algeria honey, demonstrated that it has in vitro antifungal activity against C. albicans, A. niger and Rhodotorula species. ${ }^{14-16}$
DeMera and Angert (2004) in Costa Rica reported antifungal effect of local honey towards C. albicans and a number of bacteria. ${ }^{17}$ Feas and Estevinho (2011) studied in vitro antifungal activity of Portugal organic honey. ${ }^{18}$ Meanwhile, Koc et al. (2009) reported that Turkey honey was able to inhibit forty strains of Candida spp. and Trichosporon spp. ${ }^{19}$ In addition, it also demonstrated antifungal activity towards fluconazoleresistant yeast strains.

In Australia, an in vitro study was conducted using four types of Australia honeys and their effects on Candida species. ${ }^{20}$ In an earlier study, six types of Australian honeys were tested against thirteen bacteria and C. albicans. ${ }^{10}$ Both studies used Medihoney ${ }^{\infty}$ but their results were contradictory. Lusby et al. (2005) reported that none of the honeys used, including Medihoney, have antifungal effects against C. albicans. ${ }^{10}$ In addition, another report from the Republic of Slovenia showed that all six studied Slovenian honeys lacked antifungal effect on C. albicans, A. niger and Penicillium chrysogenum. ${ }^{10}$

In South Africa, an in vitro study using three types of South Africa honey; Wasbessie, Bluegum and Fynbos, showed only Wasbessie honey had inhibitory effect on C. albicans. ${ }^{21}$ In the present study, all three types of Malaysian honeys demonstrated inhibitory effect on both C. albicans and A. niger.

While most of the studies on antifungal effects of honey involved in vitro studies, in vivo studies have also been reported. Ngatu et al. (2011) have conducted an in vivo study in the Republic of Congo, ${ }^{22}$ in which efficacy of bee products such as Acacia honey and Brazilian green propolis extract on children with fungal infections (tinea capitis and tinea versicolor) has been assessed. They have proven that bee products showed beneficial effect in treatment of superficialmycosis.

\section{CONCLUSION}

This study demonstrated in vitro antifungal activity of three Malaysian honeys, Tualang, Acacia and Kelulut, against A. niger and C. albicans, which are known pathogenic fungi of otomycosis. Hence, they showed potentials as alternative agents in the treatment of otomycosis.

\section{ACKNOWLEDGEMENT}

We would like to thank Roziawati Yusof and the Mycology Laboratory staff for their help in the mycology work. We also thank the Director of the Hospital USM, Kubang Kerian, Kelantan for granting the permission to the investigators to use patients' medical record; space and assets belong to the hospital during the process of conducting the research.

\section{CONFLICT OF INTEREST}

The authors declare no conflict of interest.

\section{REFERENCES}

1. Anderson DM, Novak PD, Keith J, Elliott MA. Dorland's illustrated medical dictionary (32 ${ }^{\text {nd }} \mathrm{Ed}$ ). Philadephia, USA: Elsevier Saunders. 2012.

2. Carney AS. Otitis externa and otomycosis. In: Gleeson M, Browning GG, Burton MJ, Clarke R, Hibbert J, Jones NS, Lund VJ, Luxon LM. and Watkinson JC. (Eds.). Scott-Brown's Otorhinolaryngology, Head and Neck Surgery (7th edition). Great Britain: Hodder Arnold. 2008;3:3351-6.

3. Kurnatowski P, Filipiak A. Otomycosis: Prevalance, clinical symptoms, therapeutic procedure. Mycoses. 2001;44(11-12):472-9.

4. Aween MM, Hassan Z, Muhialdin BJ, Eljamel YA, Al-Mabrok AS, Lani MN. Antibacterial activity of Lactobacillus acidophils strains isolated from honey marketed in Malaysia against selected multiple antibiotic resistant (MAR) Gram-positive bacteria. J Food Sci. 2012;77(7):364-71.

5. Khalil MI, Alam N, Moniruzzaman M, Sulaiman SA, Gan SH. Phenolic acid composition and antioxidant properties of Malaysian honeys. J Food Sci. $2011 ; 76(6):$ C921-8.

6. Nasir NA, Halim AS, Singh KK, Dorai AA, Haneef MN. Antibacterial properties of tualang honey and its effect in burn wound management: A comparative study. BMC Complement Altern Med. 2010;10(31):1-7. 
7. Kidd S, Halliday C, Alexiou H, Ellis D. Descriptions of Medical Fungi. $3^{\text {rd }}$ Edition. Adelaide, Australia: Newstyle Printing. 2016.

8. Anyanwu CU. Investigation of in vitro antifungal activity of honey. J Medicinal Plants Res. 2012;6(18):3512-6.

9. Kuncic MK, Jaklic D, Lapanje A, Gunde-Cimerman N. Antibacterial and antimycotic activities of Slovenian honeys. Br J Biomed Sci. 2012; 69(4):154-8

10. Lusby PE, Coombes AL, Wilkinson JM. Bactericidal activity of different honeys against pathogenic bacteria. Arch Med Resp. 2005;36(5):464-7.

11. Estevinho ML, Afonso SE, Feas X. Antifungal effect of lavender honey against Candida albicans, Candida krusei and Cryptococcus neoformans. J Food Sci Technol. 2011;48(5):640-3.

12. Obaseiki-Ebor EE, Afonya TC. In vitro evaluation of the anticandidiasis activity of honey distillate (HY-1) compared with that of some antimycotic agents. J Pharm Pharmaco. 1984;36(4):283-4.

13. Boukraa L, Bouchegrane S. Additive action of honey and starch against Candida albicans and Aspergillus niger. Rev Iberoam Micol. 2007;24(4):309-11.

14. Moussa A, Noureddine D, Saad A, Hebbeb A, Ahmed B. Antifungal activity of a combination of Algeria honey and starch of ginger against Aspergillus niger. Int J Microbiol. 2011;2(3):263-6.

15. Moussa A, Noureddine D, Hammoudi SM, Saad A, Bourabeh A, Houari $H$.
Additive potential of ginger starch on antifungal potency of honey against Candida albicans. Asian Pac J Trop Biomed. 2012;2(4):253-5.

16. Moussa A, Noureddine D, Saad A, Abdelmelek M, Abdelkader B. Antifungal activity of four honeys of different types from Algeria against pathogenic yeast: Candida albicans and Rhodotorula sp. Asian Pac J Trop Biomed. 2012;2(7):554-7.

17. DeMera JH, Angert ER. Comparison of the antimicrobial activity of honey produced by Tetragoniscaangustula (Meliponinae) and Apismellifera from different phytogeographic regions of Costa Rica. Apidologie. 2004;35:411-7.

18. Feas $\mathrm{X}$, Estevinho ML. A survey of the in vitro antifungal activity of heather (Erica sp.) organic honey. J Med Food. 2011;14(10):1284-8.

19. Koc AN, Silici S, Ercal BD, Kasap F, Hormet-Oz HT, Mavus-Buldu H. Antifungal activity of Turkish honey against Candida spp. and Trichosporon spp; An in vitro evaluation. Med Mycol. 2009;47(7):707-12.

20. Irish J, Carter DA, Shokohi T, Blair SE. Honey has an antifungal effect against Candida species. Med Mycol. 2006;44(3):289-91.

21. Theunissen F, Grobler S, Gedalia I. The antifungal action of three South African honeys on Candida albicans. Apidologie. 2001;32(4):371-9.

22. Ngatu NR, Saruta T, Hirota R, Eitoko M, Muzembo BA, Matsui T, et al. Antifungal efficacy of Brazilian green propolis extracts and honey on Tinea capitis and Tinea versicolor. Eur J Integrative Med. 2011;3(4):281-7.

Article History: Submission Date : 26-12-2017; Revised Date : 17-02-18; Acceptance Date : 02-04-2018.

Cite this article: Hamid Z, Mohamad I, Harun A, Salim R, Sulaiman SA. Antifungal effect of Three Local Malaysian Honeys on Selected Pathogenic Fungi of Otomycosis: An in vitro Evaluation. J Young Pharm. 2018;10(4):414-7. 